\title{
PERANCANGAN SISTEM MANAJEMEN UANG KAS PADA RT 02 RW 03 CIMANGGIS DEPOK
}

\author{
Muhammad Bahar Mubarok ${ }^{1}$, Ega Shela Marsiani ${ }^{2}$, Natalia Tri Astuti ${ }^{3}$ \\ Program Studi Teknik Informatika, Fakultas Teknik dan Ilmu Komputer, \\ Universitas Indraprasta PGRI \\ Jalan Raya Tengah No 80, Kelurahan Gedong, Pasar Rebo, Jakarta Timur \\ muhammadbaharmubarok@gmail.com ${ }^{1}$, egashela@gmail.com², natnatalia.lia@gmail.com ${ }^{3}$
}

\begin{abstract}
Abstrak
Perancangan pengelolaan uang kas mencakup kumpulan prosedur yang melaksanakan, mencatat, mengkalkulasi, membuat dokumen dan informasi untuk keperluan manajemen dan bagian lain yang berkepentingan, mulai dari pemasukan sampai pengeluaran. Manajemen catatan, dan laporan yang dikoordinasi sedemikian rupa untuk menyediakan informasi uang kas yang dibutuhkan oleh manajemen guna memudahkan pengelolaan uang kas di RT 02 RW 03 Cimanggis Depok. Kualitas pelayanan sangat tergantung pada kelancaran pendanaan untuk membiayai semua aktivitas yang dilakukan. Dalam hal ini Ketua RT 02 RW 03 Cimanggis Depok harus dapat mengelola uang kas sumber daya yang dimilikinya dengan sebaik mungkin. Proses manajemen pengelolaaan uang kas di RT 02 RW 03 Cimanggis Depok masih secara manual sehingga sering terjadi kesalahan double booked pada waktu yang sama. Perancangan aplikasi ini bertujuan untuk membantu dan mempermudah RT 02 RW 03 Cimanggis Depok dalam mengelola uang kas untuk memberikan pelayanan yang sebaik-baiknya kepada publik. Metode penelitian ini menggunakan metode Research Development. Sehingga perancangan sistem tetap sesuai dengan prosedur yang ada pada RT 02 RW 03 Cimanggis Depok.
\end{abstract}

Kata Kunci: Java, Kas, Manajemen, Sistem

\begin{abstract}
The cash management plan includes a set of procedures that carry out, record, calculate, create documents and information for the purposes of management and other interested parties, from income to expenditure. Management of records and reports are coordinated in such a way as to provide cash information needed by management to facilitate cash management at RT $02 \mathrm{RW} 03$ Cimanggis Depok. The quality of service is very dependent on the smoothness of funding to finance all activities carried out. In this case the Head of RT 02 $R W 03$ Cimanggis Depok must be able to manage the cash resources of his resources as well as possible. The cash management process at RT 02 RW 03 Cimanggis Depok is still manual, so double booked errors often occur at the same time. The design of this application aims to help and facilitate RT 02 RW 03 Cimanggis Depok in managing cash to provide the best possible service to the public. This research method uses the Research Development method. So that the design system remains in accordance with the existing procedures in RT 02 RW 03 Cimanggis Depok.
\end{abstract}

Keywords: Cash, Java, Management, Systems

\section{PENDAHULUAN}

Perancangan pengelolaan uang kas yang mencakup kumpulan prosedur yang melaksanakan, mencatat, mengkalkulasi, membuat dokumen dan informasi untuk keperluan manajemen dan bagian lain yang berkepentingan, mulai dari pengeluaran sampai yang di peroleh RT 02 RW 03 Cimanggis Depok. Dalam mengelola uang kas diperlukan efisiensi dan efektifitas pada pengolahan data dan perlunya pelayanan yang sebaik-baiknya kepada publik.

Proses manajemen uang kas di RT 02 RW 03 Cimanggis Depok masih manual sehingga sering terjadi kesalahan double booked pada waktu yang sama dan menyebabkan ketidak akuratan laporan manajemen pengelolaan uang kas.

Oleh karena itu, sistem ini diharapkan dapat memecahkan masalah yang terjadi pada proses manajemen uang kas di RT 02 RW 03 Cimanggis Depok sehingga tidak terjadi kesalahan dan membuat proses pengolaan kas lebih akurat. 
Sistem merupakan suatu jaringan kerja dari prosedur-prosedur yang saling berhubungan berkumpul bersama-sama untuk melakukan suatu kegiatan atau menyelesaikan suatu sasaran tertentu, dimana dari sistem tersebut akan siap untuk merancang bangun implementasi dan penggambaran perancangan dan pembuatan sketsa atau pengaturan dari berberapa elemen yang terpisah dalam kesatuan yang utuh (Wardawati, 2016).

Berdasarkan pada latar belakang yang telah diuraikan, maka peneliti dapat menelaah beberapa permasalahan yang terjadi pada RT 02 RW 03 Cimanggis Depok yaitu bagaimana mengatasi bukti pengeluaran kas yang kurang akurat, bagaimana pencatatan kas sudah sesuai dan layak, bagaimana memberikan informasi kas terbaru dengan cepat, bagaimana cara memberikan laporan dengan akurat dan dapat dijadikan bahan pertimbangan, dan bagaimana implementasi dari pengembangan sistem pengelolaan uang yang tepat dan sesuai prosedur pada RT 02 RW 03 Cimanggis Depok.

Penelitian ini diharapkan memberikan suatu fungsi praktis dan akurat dalam pengolahan data kas yang dapat membantu kinerja petugas RT 02 RW 03 Cimanggis Depok.

\section{PENELITIAN RELEVAN}

Penelitian oleh Beliana Kartikawati dengan judul Perancangan Sistem Manajemen Pengelolaan Uang Kas di Hotel Kartika Berbais Java. Tujuan dari penelitian ini adalah untuk mengatasi masalah sistem pengelolaan kas hotel yang masih manual dan mengharuskan bendahara untuk mengkalkulasikan dan mencatat dana kas yang begitu banyak. Dengan adanya sistem manajemen pengelolaan uang kas hotel ini, bendahara tidak perlu mengeluarkan banyak tenaga untuk menghitung jumlah nominal dana kas yang ada begitu banyak (Kartikawati, 2012).

Penelitian oleh Robby Mahendra dengan judul Sistem Administrasi Pengelolaan Uang Kas Penyewaan GOR Samina berbasis Java. Tujuan dari penelitian ini adalah untuk mengatasi masalah pengelolaan kas masuk dan keluar yang terjadi pada GOR Samina, sistem pembukuan yang masih manual membuat pengambilan keputusan dari laporan kas yang belum akurat menjadi hambatan besar. Dengan adanya aplikasi ini diharapkan output yang dihasilkan oleh sistem akurat dan dapat dijadikan bahan pertimbangan (Mahendra, 2012).

\section{METODE PENELITIAN}

Metode Research Development yaitu suatu metode penelitian berdasarkan pada fakta dan menggunakan analisis perbandingan dengan tujuan menetapkan konsep, membuktikan teori, mengembangkan teori, pengumpulan dan analisis data dalam waktu yang bersamaan. Dalam riset ini data merupakan sumber teori atau teori berdasarkan data secara empiris, bukan membangun teori secara deduktif logis, data empirik yang diperoleh secara sistematis (Sidharta, 2015). Dalam metode pengumpulan data yang dilakukan oleh penulis untuk mendapatkan data-data serta informasi yang mendukung penyempurnaan hasil dari penelitian ini antara lain:

\section{a. Observasi}

Teknik ini merupakan teknik pengamatan secara langsung kegiatan yang berlangsung pada RT 02 RW 03 Cimanggis Depok yaitu serta data-data yang akan disajikan sebagai penyusun laporan tugas akhir.

b. Wawancara

Teknik wawancara merupakan suatu teknik dimana peneliti narasumber berhadapan langsung, saling bertukar pikiran dan bertukar informasi mengenai permasalahan yang telah ditentukan.

\section{c. Sumber Data Sekunder}

Data sekunder merupakan cara pengumpulan data dengan cara mempelajari data yang telah tersedia pada RT 02 RW 03 Cimanggis Depok kepada peneliti.

\section{HASIL DAN PEMBAHASAN}

\section{Analisis Permasalahan}

Berdasarkan dari hasil penelitian secara langsung sistem pengelolaan kas pada RT 02 RW 03 Cimanggis Depok, maka peneliti dapat menganalisis permasalahan yang terjadi yaitu: 
1. Laporan yang digunakan pada RT 02 RW 03 untuk bukti pengeluaran uang kas kurang akurat, seperti bukti laporan pengeluaran uas kas dengan jumlah yang uang dikeluarkan terkadang kurang akurat karna tidak di update secara otomatis.

2. Pencatatan dalam buku arsip manajemen pengelolaan uang selama jangka waktu tertentu menyebabkan kesulitan dalam melakukan pengecekan persediaan dan perhitungan jumlah pendapatan.

3. Informasi tidak up to date karena keterlambatan dalam proses pencarian.

4. Laporan tidak dapat dijadikan bahan pertimbangan karena output yang dihasilkan belum akurat.

5. Implementasi dan penerapan prosedur pengelolaan uang kas masih kurang tepat.

\section{Alternatif Penyelesaian Masalah}

Berdasarkan analisis permasalahan yang ada pada RT 02 RW 03 Cimanggis Depok dan masih menjadi permasalahan sampai dibuatnya penelitian ini, maka dari itu peneliti dapat menyarankan beberapa alternatif dalam menyelesaikan masalah tersebut antara lain:

1. Sistem perancangan manajemen pengelolaan uang kas RT 02 RW 03 Cimanggis Depok agar pengeluaran uang kas lebih akurat.

2. Pengembangan pencatatan kas sistem manajemen pengelolaan uang kas yang sesuai dan layak diterapkan pada RT 02 RW 03 Cimanggis Depok.

3. Sistem perancangan manajemen pengelolaan uang kas RT 02 RW 03 Cimanggis Depok memberikan informasi kas terbaru dengan cepat.

4. Sistem perancangan manajemen pengelolaan uang kas RT 02 RW 03 Cimanggis Depok dapat memberikan laporan dengan akurat dan dapat dijadikan bahan pertimbangan.

5. Implementasi dari pengembangan sistem pengelolaan uang yang tepat dan sesuai dengan prosedur pada RT 02 RW 03 Cimanggis Depok.

Berikut merupakan Diagram Alir Data Konteks pengelolaan kas pada RT 02 RW 03 Cimanggis Depok yang diusulkan:

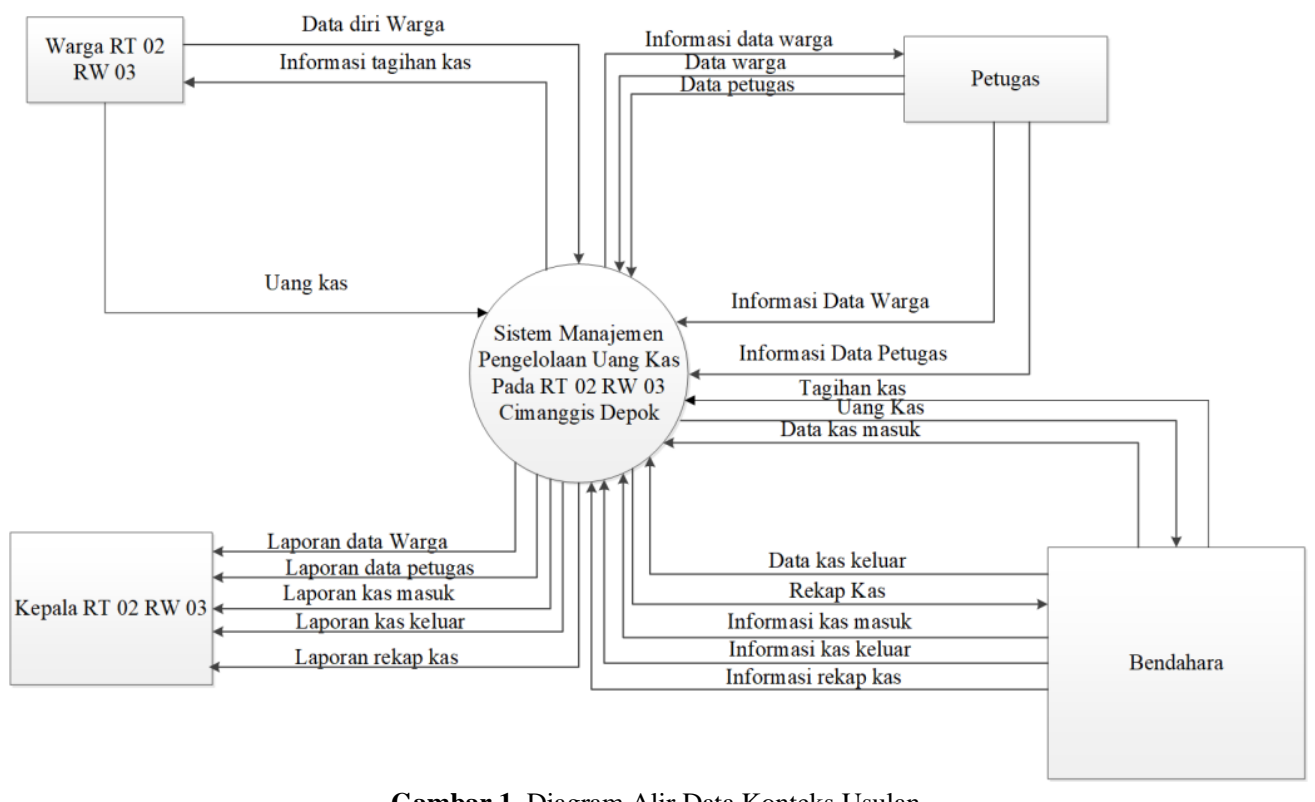

Gambar 1. Diagram Alir Data Konteks Usulan

Pada Gambar 1 menunjukkan bahwa Sistem Manajemen Uang Kas ini memiliki empat entitas yang harus saling berkoordinasi. 


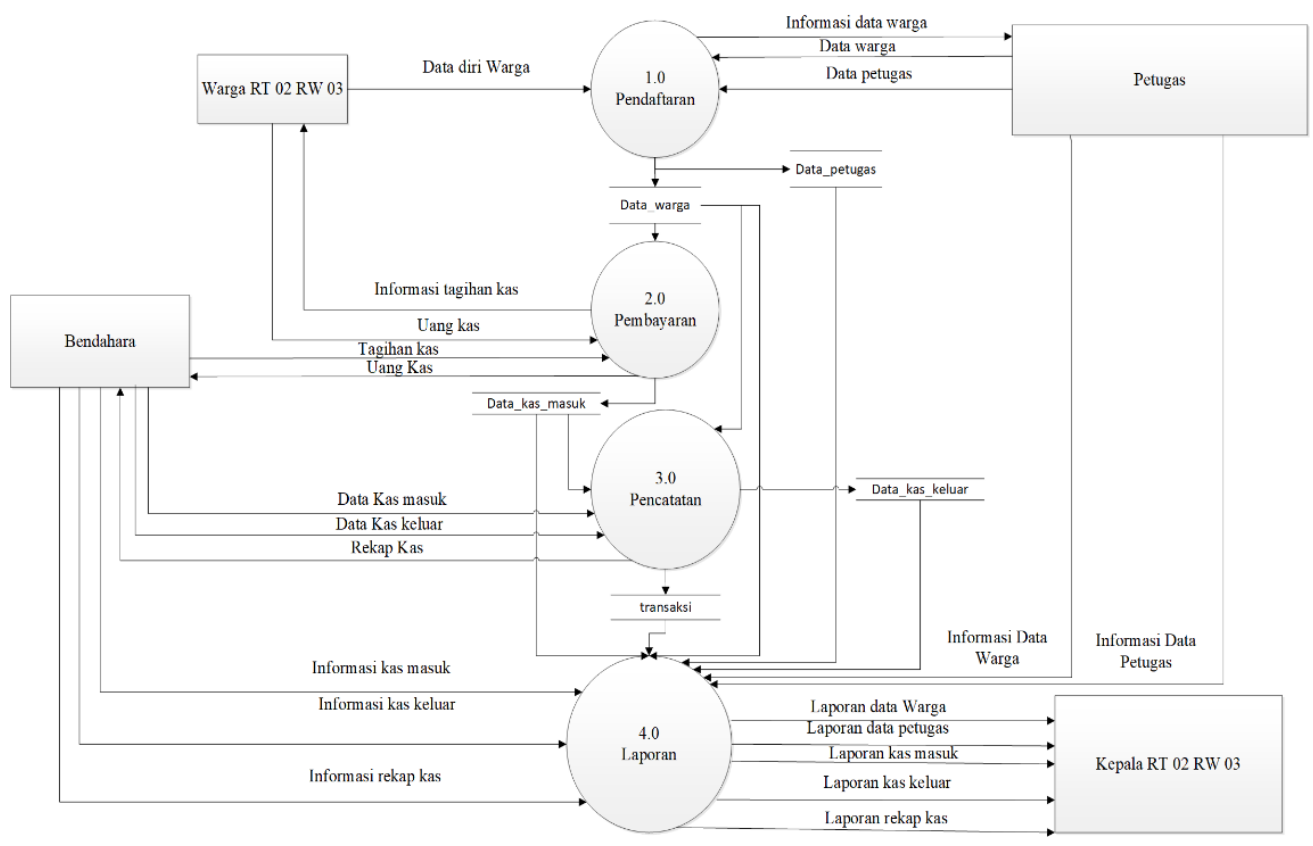

Gambar 2. Diagram Alir Data Nol Usulan

Pada Gambar 2 menunjukkan aliran data pada Sistem Manajemen Uang Kas yang diusulkan.

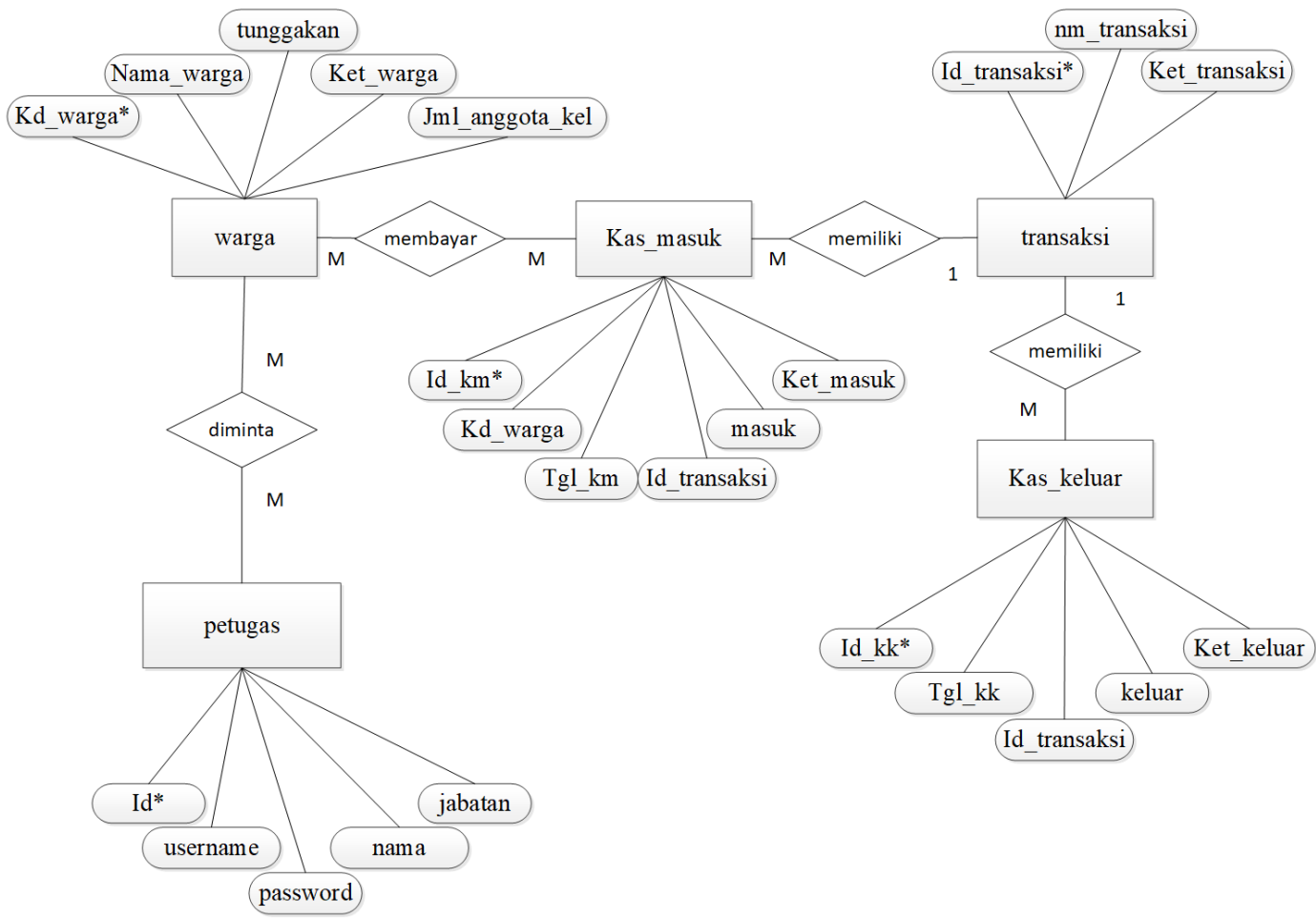

Gambar 3. Entity Relationship Diagram

Pada Gambar 3 merupakan relasi antara entitas yang dimana terbentuk menjadi sebuah diagram yang masing - masing dari entitas memiliki attributnya sendiri. 


\section{Tampilan Aplikasi}

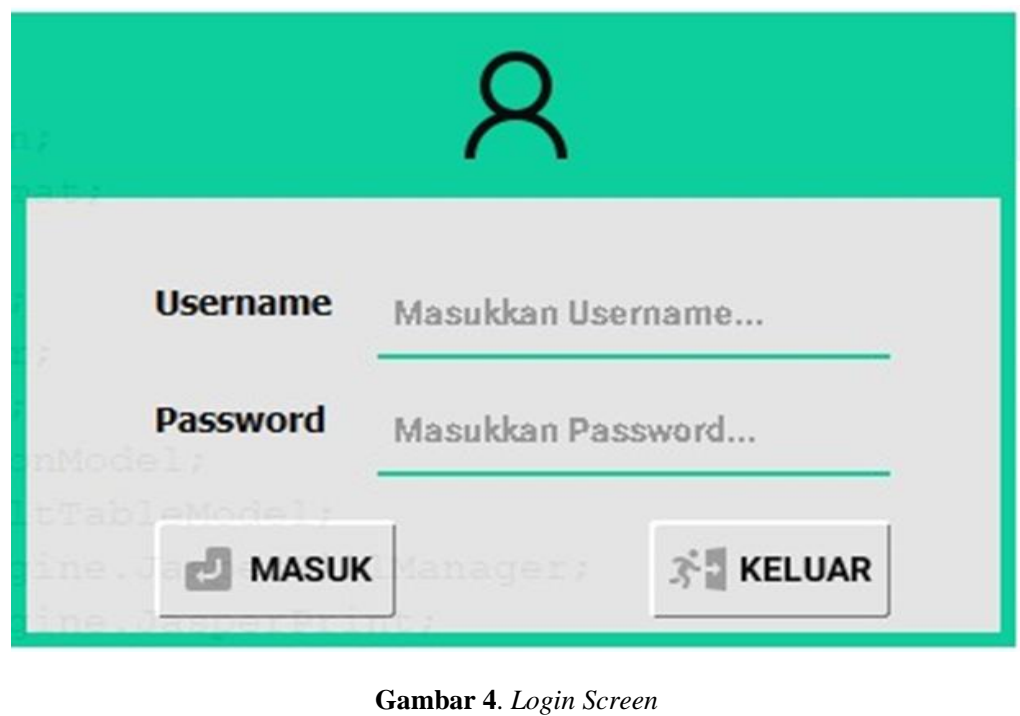

Pada Gambar 4 merupakan menu login, rancangan ini terdapat pada awal program, menu login digunakan sebagai kata kunci sebelum kita memasuki program utama. program ini tidak sembarangan orang dapat mengakses dan kerahasiaan tetap terjaga dengan baik.

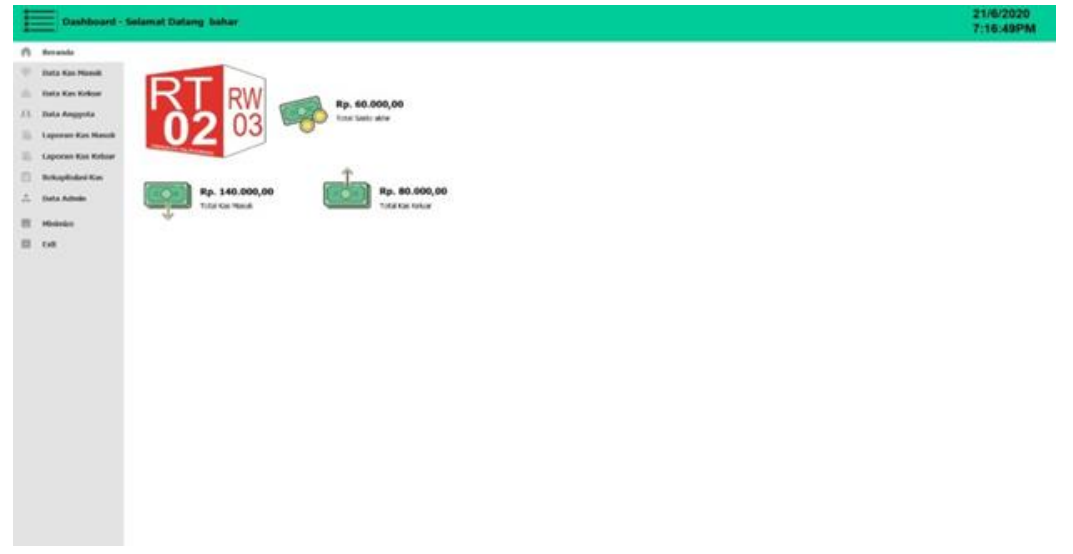

Gambar 5. Menu Screen

Pada Gambar 5 menu utama tersedia menu bar yang terdiri dari menu input data yang digunakan untuk menginput data-data yang terdiri dari data kas masuk, data kas keluar, data anggota, laporan kas masuk, laporan kas keluar, rekapitulasi kas dan admin manajemen pengelolaan uang kas juga tersusun dari menu file terdiri atas menu logout dan exit yang digunakan keluar dari aplikasi tersebut.

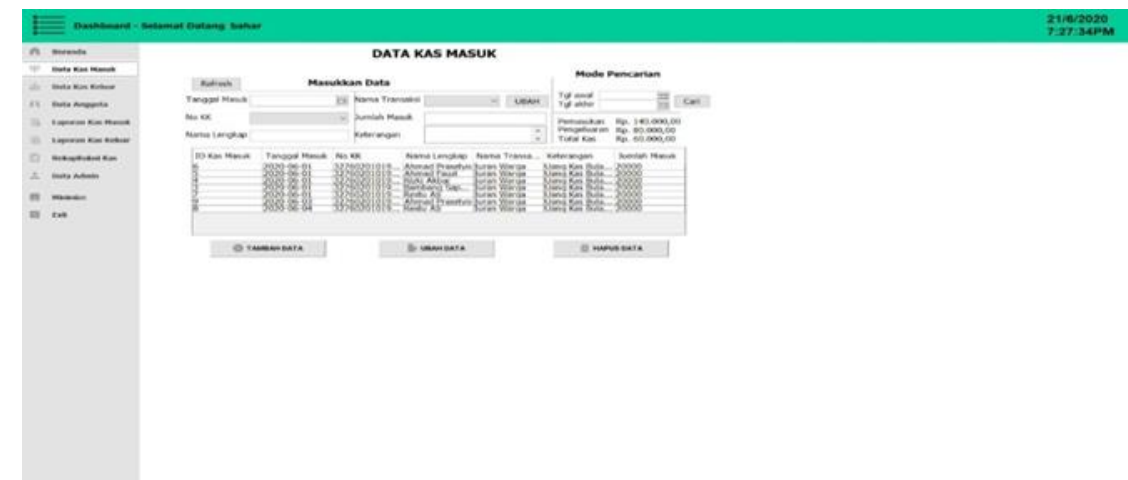

Gambar 6. Kas Masuk 
Pada Gambar 6 terdapat tampilan untuk menambah, mengubah, menghapus dan memanggil data kas masuk yang ada dalam database.

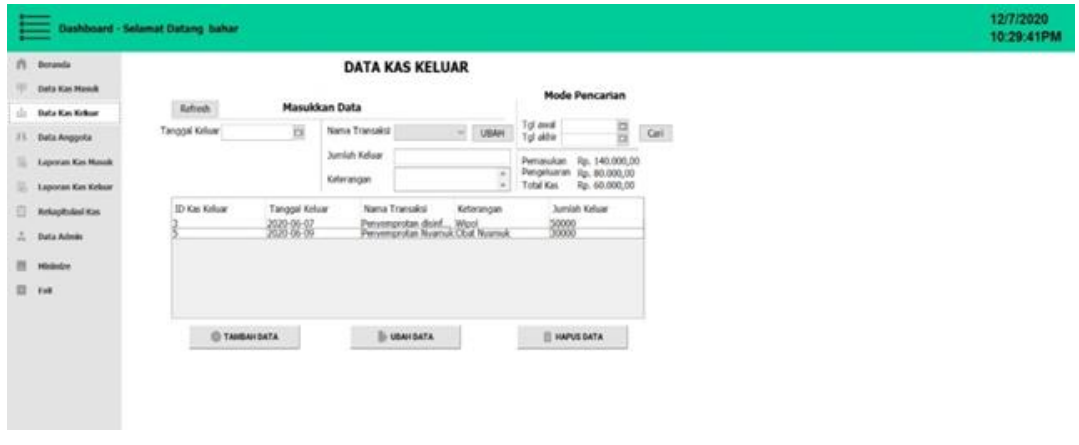

Gambar 7. Kas Keluar

Pada Gambar 7 terdapat tampilan untuk menambah, mengubah, menghapus dan memanggil data kas keluar yang ada dalam database.

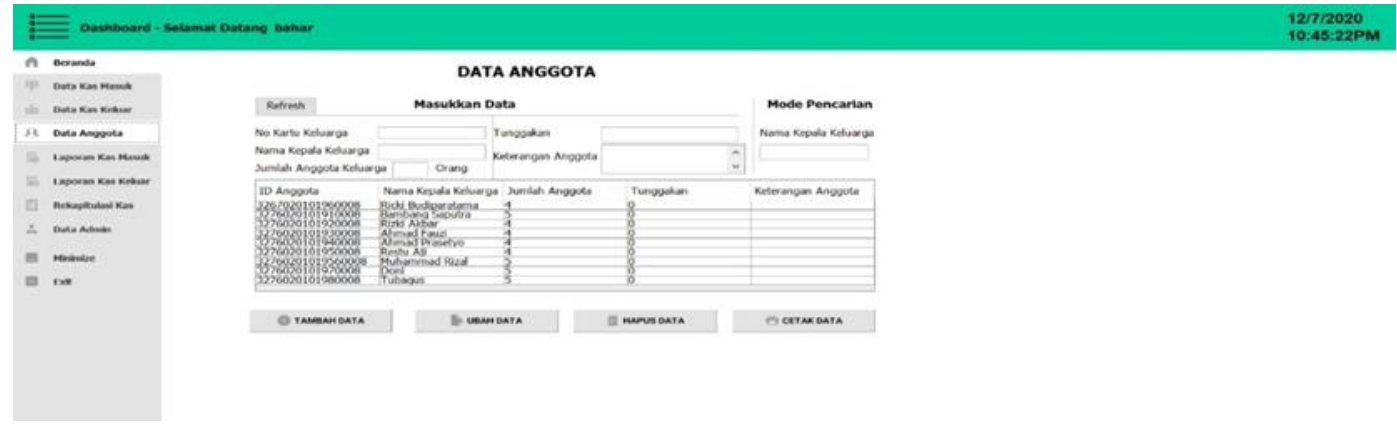

Gambar 8. Tampilan Data Warga

Pada Gambar 8 terdapat tampilan untuk menambah, mengubah, menghapus dan memanggil data warga yang ada dalam database.

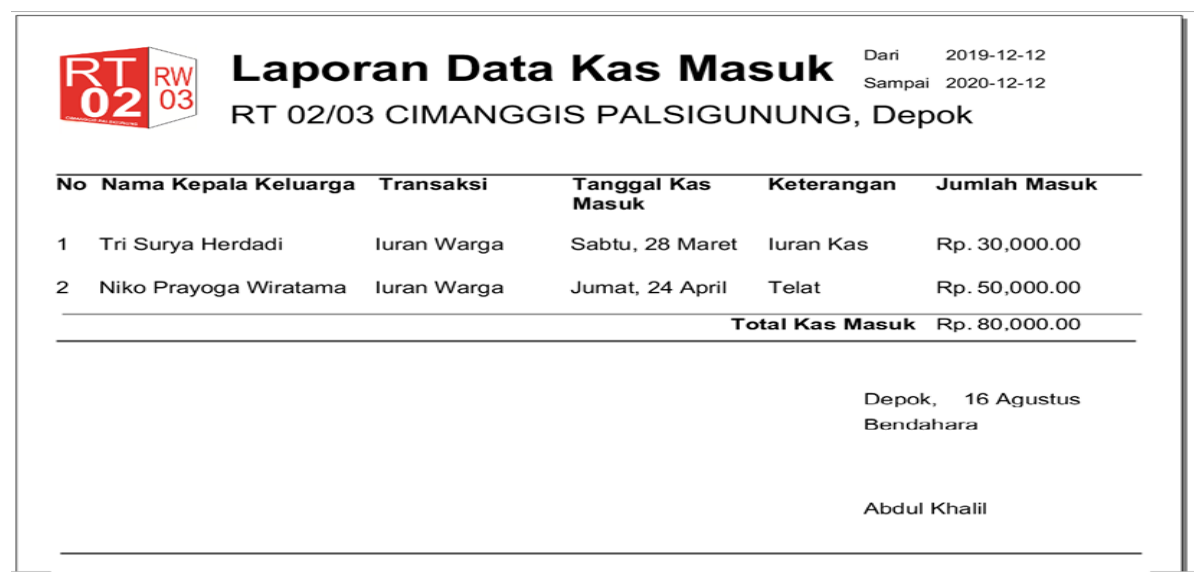

Gambar 9. Laporan Kas Masuk

Pada Gambar 9 merupakan laporan data kas masuk yang diambil melalui ireport yang tersimpan dalam database. 


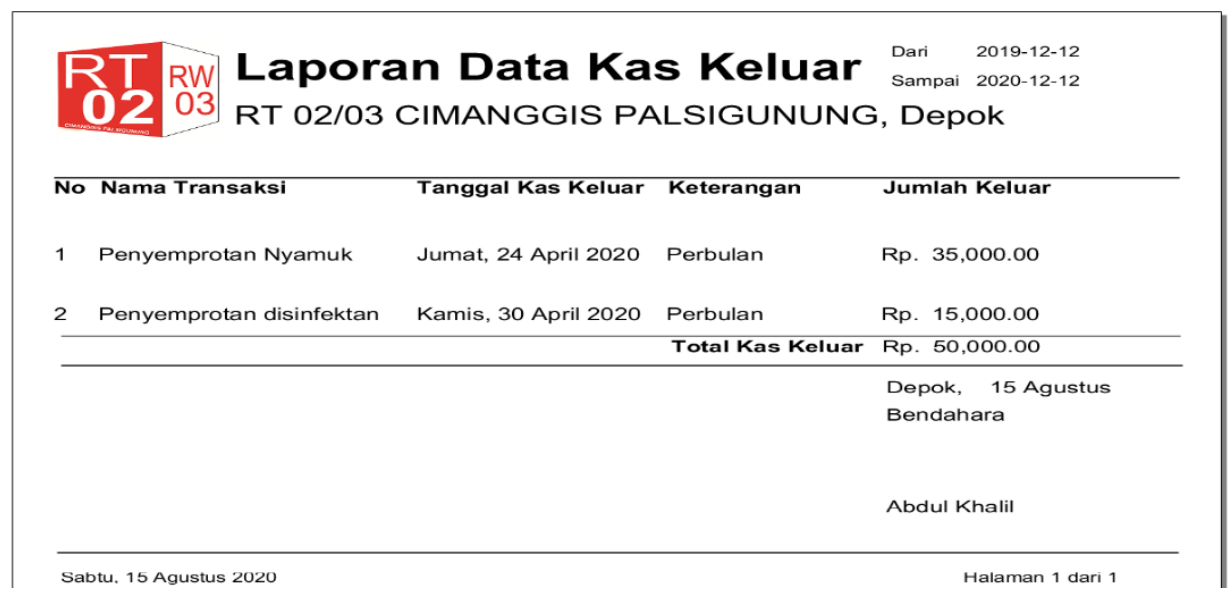

Gambar 10. Laporan Kas Keluar

Pada Gambar 10 merupakan laporan data kas keluar yang diambil melalui ireport yang tersimpan dalam database.

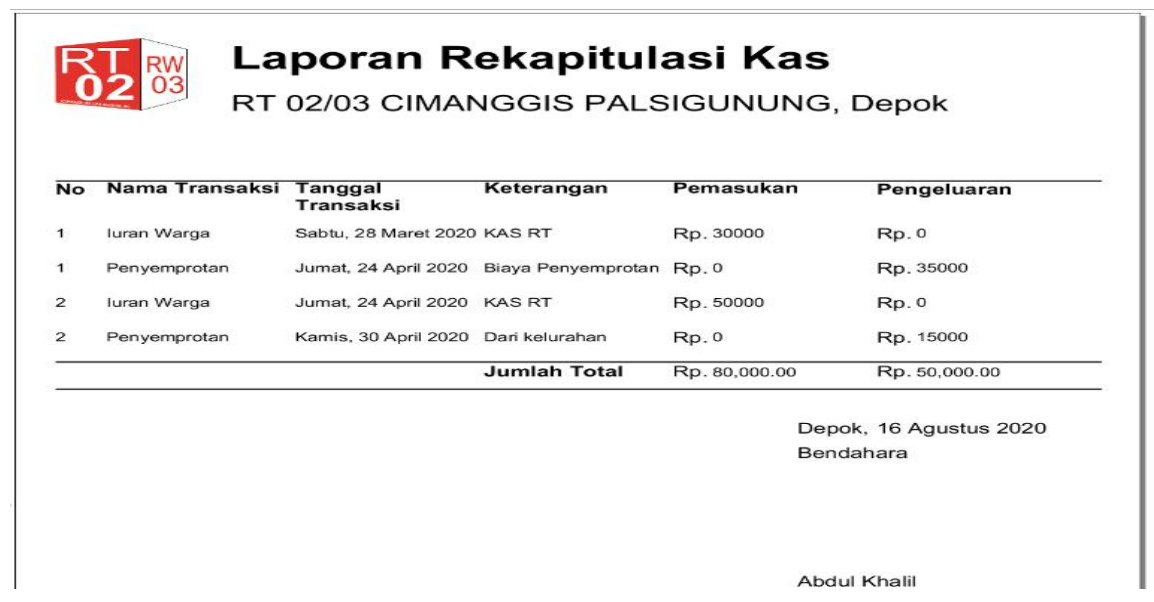

Gambar 11. Laporan Rekapitulasi Kas

Pada Gambar 11 merupakan laporan data rekapitulasi kas yang diambil melalui ireport yang tersimpan dalam database.

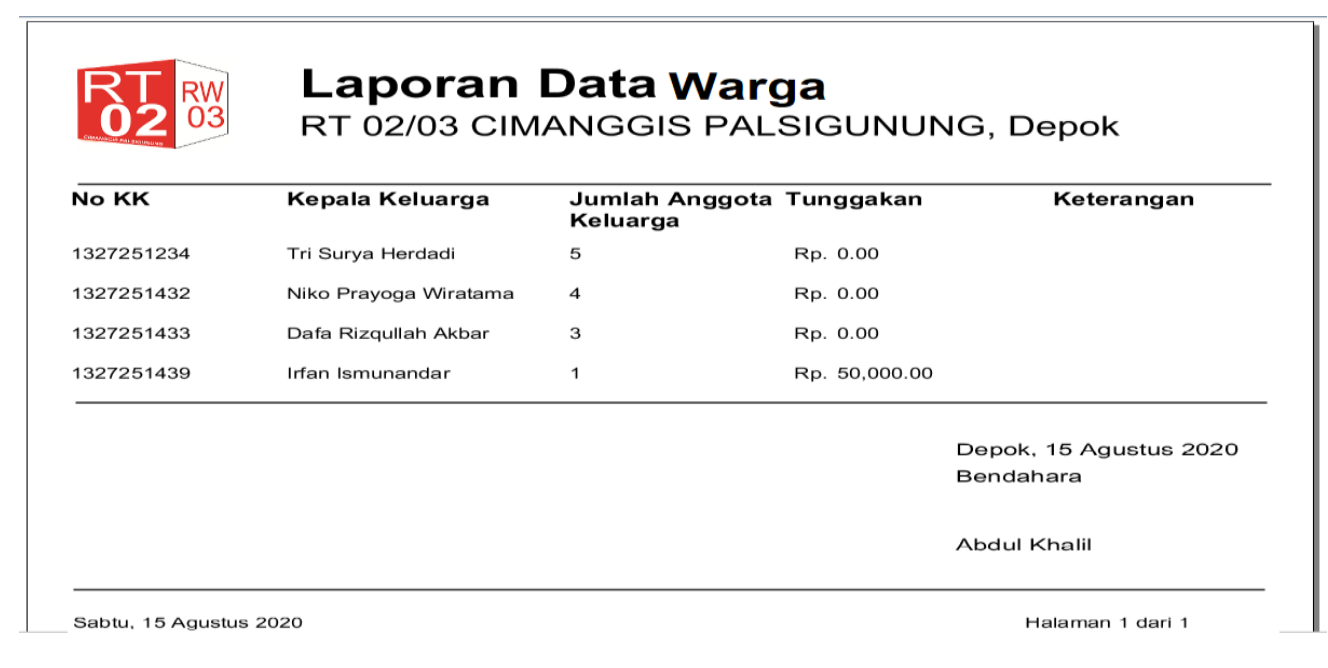

Gambar 12. Laporan Data Warga

Pada Gambar 12 merupakan laporan data warga yang diambil melalui ireport yang tersimpan dalam database. 


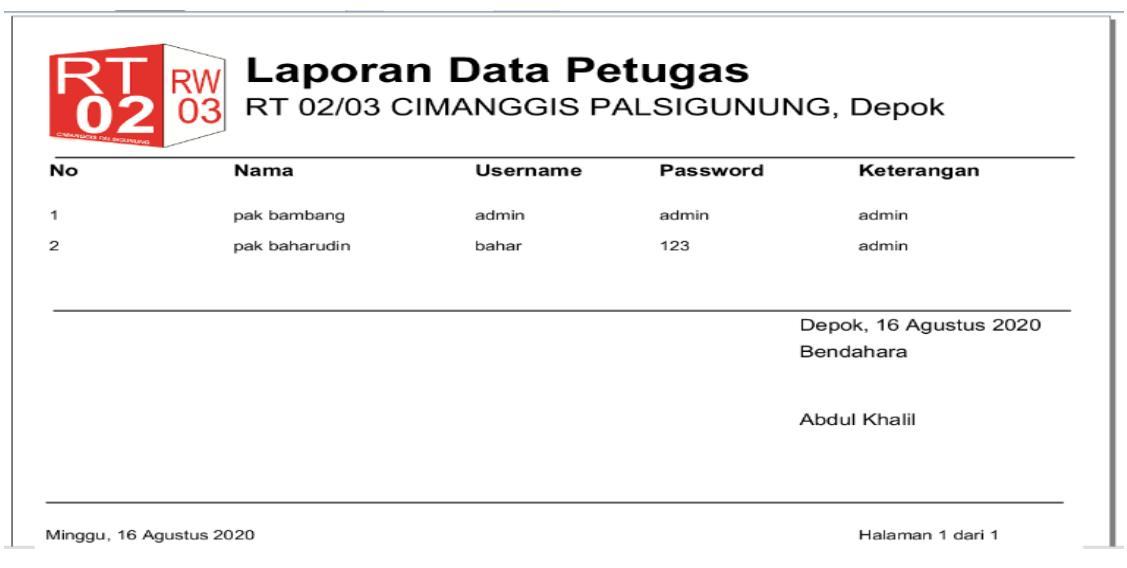

Gambar 13. Laporan Data Petugas

Pada Gambar 13 merupakan laporan data petugas yang diambil melalui ireport yang tersimpan dalam database.

\section{SIMPULAN}

Berdasarkan hasil dari pembahasan yang telah diuraikan sebelumnya dan menyesuaikan hasil dari Sistem Perancangan Manajemen Pengelolaan Uang Kas Pada RT 02 RW 03 Cimanggis Depok, maka kesimpulan yang diperoleh peneliti adalah sebagai berikut:

1. Dokumen yang digunakan pada RT 02 RW 03 untuk bukti pengeluaran uang kas lebih akurat.

2. Pencatatan dalam buku arsip manajemen pengelolaan uang selama jangka waktu tertentu lebih mudah dalam melakukan pengecekan persediaan dan perhitungan jumlah pendapatan.

3. Informasi up to date dalam proses pencarian data.

4. Laporan informasi yang akurat berdampak pada efektifitas dan efisiensi dalam pengambilan keputusan, terutama berkaitan dengan keputusan pengelolaan uang kas.

5. Prosedur manajemen pengelolaan uang kas yang dilakukan oleh RT 02 RW 03 Cimanggis Depok menjadi lebih tinggi sehingga output berupa informasi lebih akurat dan relevan.

\section{DAFTAR PUSTAKA}

Kartikawati, Beliana. (2012). Perancangan Sistem Manajemen Pengelolaan Uang Kas di Hotel Kartika Berbais Java. Skripsi. Sarjana, Universitas Indraprasta PGRI, Fakultas Teknik Informatika, Jakarta.

Mahendra, Robby. (2012). Sistem Administrasi Pengelolaan Uang Kas Penyewaan GOR Samina berbasis Java. Skripsi. Sarjana, Universitas Indraprasta PGRI, Fakultas Teknik Informatika, Jakarta.

Meliono. (2014). Sistem Basis Data. Yogyakarta: Andi Offset.

Mulianto (2015). Pengetahuan Komputer dan Teknologi Informasi. Yogyakarta: Sistem Informasi.

Sahdiamin. (2015). Membangun Website dengan Adobe Photoshop dan Macromedia Dreamweaver. Jakarta.

Saridah. (2016). Teknik Pemrograman Web PHP. Bandung: Informatika

Sidharta. (2015). Analisis dan Desain Sistem Informasi. Yogyakarta: Andi Offset.

Sugiyono. (2013). Metode Penelitian Kuanititatif, Kualitatif, Dan R\&D. Bandung: Penerbit Alfabet.

Wardawati. (2016). Sistem Basis Data. Bandung: Karya Pustaka.

Zarkasi (2016). Pengetahuan Komputer dan Teknologi Informasi. Yogyakarta: Sistem Informasi. 